\title{
Health status and physical activity among academic and non academic staffs in higher education
}

Nurul Qomariyah, Sitti Nur Djannah

Faculty of Public Health, Universitas Ahmad Dahlan, Indonesia

\begin{tabular}{l}
\hline \hline Article Info \\
\hline Article history: \\
Received Jan 10, 2019 \\
Revised Feb 20, 2019 \\
Accepted Feb 26, 2019 \\
\hline Keywords: \\
Health status \\
Higher education \\
Inhibiting factors \\
Physical activity \\
Supporting factors \\
\hline
\end{tabular}

\begin{abstract}
Being physically active is reducing the risk of non-communicable diseases. Mixed method study was conducted to analyze health status and explore supporting and inhibiting factors of physical activity among academic and non academic staff in higher education. A total of 83 respondents were met the inclusion and exclusion criteria. The majority of Universitas Ahmad Dahlan (UAD) staffs are physically active and overweight. No significant health problems are found. Individual, social and environmental factors are identified as factors that can support and inhibit physical activity. Policies at the faculty and university level are needed as well as cross-sectoral collaboration with related parties to support physical activities in UAD.
\end{abstract}

Copyright (C) 2019 Institute of Advanced Engineering and Science. All rights reserved.

\section{Corresponding Author:}

Nurul Qomariyah,

Faculty of Public Health, Universitas Ahmad Dahlan,

Kampus 3, Jl. Prof. Dr. Soetomo, UH, Yogyakarta, Indonesia.

Email: nurul.qomariyah@ikm.uad.ac.id

\section{INTRODUCTION}

Healthy is a state of well-being physically, mentally and socially [1]. Being physically active plays an important role in ensuring health and well-being [2]. Regular moderate intensity of physical activity such as walking, cycling, or participating in sports activities - proved to have a positive impact on health, namely reducing the risk of non-communicable diseases, such as heart disease, hypertension, stroke, diabetes, cancer, and depression. Meanwhile physical activity also improves muscle, heart, and respiratory fitness; improve bone health so that it can reduce the risk of falls and fractures and help control body weight by maintaining the balance of intake and energy expenditure [3].

WHO has formulated the recommended amount of physical activity according to age groups (ages 5-17 years, 18-64, and >65 years). Recommendations for adults with an age range of 18-64 years are the accumulation of moderate level of physical activity for 150 minutes/week or at least doing vigorous physical activity for 75 minutes per week, or an equivalent combination of moderate and vigorous physical activity [4]. The best way to be physically active can be achieved by integrating physical activity at least moderate intensity physical activity (such as brisk walking, and other activities that make the body warmer and breathe faster) into everyday life [5].

There are multiple sources of evidence to indicate that energy expenditure requirements have reduced in many facets of daily life as well in the workplace over the past 50 years. These include: fewer jobs requiring physical work; increased labour-saving technology in the home, work and retail environments; changes in work and shopping patterns - from local to distant - that have resulted in greater reliance on motorized transport; increased self-sufficiency in the home, including entertainment, food storage and preparation, controlled climates and greater comfort; reductions in walking and cycling [6]. Those changes will increase the risk of non-communicable diseases at a younger age [7]. 
Everyone must be supported for physically active and make it as part of daily activities. Physical environment (such as land use patterns, transportation systems, urban designs, and green spaces); and social environment (such as income, justice, culture and social support) are identified as factors that support physical activity [5], [8]. Programs that are individually designed according to individual needs are proven to be better in regulating the level of participation and maintaining it [9].

Education about the importance of physical activity for young adults and providing opportunities to gain social benefits from physical activity would increase perceived benefits and reduce perceived costs of physical activity. Workplace cultural norms with respect to physical activity must also be addressed to create a shift in physical activity participation [10]. Physical education obtained in elementary, middle and high school is expected to support physically active lifestyle throughout life [11].

Therefore, a study is needed to analyze health status and explore supporting and inhibiting factors of physical activity among academic and non academic staff in higher education. UAD is one of the private universities in Indonesia. Located in Yogyakarta and has founded in 1960, currently, it has 12 faculties, 660 academics staffs and 357 non academic staffs [12].

\section{RESEARCH METHOD}

This type of research is mixed method, employed analytical descriptive research using a cross sectional study approach with a sequential explanatory design method. The study was conducted after obtaining ethical aprroval from Research Ethic Committee UAD number 011712164.

Quantitative study was conducted to des cribe the participation of respondent in physical activity and to analyze the relationship between physical activity and BMI, blood pressure, blood glucose, and cholesterol. Global Physical Activity Questionnaire from WHO was used to see participation of respondents in physical activity. Based on previous study, the reability of GPAQ is strong (Kappa 0.67 to 0.73 ) [13]. Meanwhile, the validity is moderate $(\mathrm{r}=0.48)$, based on its correlation to accelerometer [14]. This questionnaire was also used by previous study in UAD [15]. Health data such as the body mass index (BMI), blood pressure, blood sugar (On Call EZ II), and cholesterol (Accutrend) were obtained through a health examination program for academic and academic staff of UAD which is held December $28^{\text {th }}, 2017$ and January $4^{\text {th }}, 2018$ as part of $57^{\text {th }}$ UAD anniversary.

Inclusion criteria: registered as academic or non academic staffs at UAD who are participate in health examination at $57^{\text {th }}$ UAD anniversary, age $>18$ years, complete a physical activity questionnaire. Exclusion criteria: cholesterol test results: low or high (no precise result), incomplete physical activity questionnaire.

Quantitative data analysis by Chi square with 0.05 level of confidence was conducted to see the relationship between those variables. This data continued with qualitative research with in-depth interviews to explore factors that support and inhibit physical activity.

Quantitative study was conducted to explore factors that support and inhibit physical activity. Participant in this study were selected from two groups of respondent: physically active and not physically active groups. Interviews were done individually based on agreement from the respondents and the researcher. Quantitative data analysis was conducted in several steps. The result of interview is translated into transcript soon after the interview. Open coding was conducted to analyse the transcript.

\section{RESULTS AND DISCUSSION}

\subsection{Quantitative analysis}

\subsubsection{Univariate analysis}

A total of 83 respondents were met the inclusion and exclusion criteria. The proportion of respondents by sex showed a balance, namely $48 \%$ of men and $51.8 \%$ of women. The minimum age of respondents is 20 years old and the maximum is 70 years old, with an average age of 37.7 years. The majority of respondents are non academic staff (63.9\%), and $91.6 \%$ live far from UAD's campus.

Majority of respondents met WHO recommendations for physical activity (66.3\%) and the majority of respondents are overweight and obese (62.7\%), 47\% are pre-hypertensive and hypertensive, $89.2 \%$ had normal blood sugar levels, and $71.1 \%$ have normal cholesterol levels. The overall picture of respondents in this study can be seen in Table 1.

Int. J. Eval. \& Res. Educ. Vol. 8, No. 1, March 2019: 97 - 102 
Table 1. Characteristic of respondents

\begin{tabular}{ccccc}
\hline No & & Category & Frequency & Persentage \\
\hline 1 & Sex & Male & 40 & 48.2 \\
& & Female & 43 & 51.8 \\
2 & Occupation & Academic staff & 30 & 36.1 \\
& & Non academic staff & 53 & 63.9 \\
3 & Residency & Live far from UAD & 76 & 91.6 \\
& & Live near from UAD & 7 & 8.4 \\
4 & Physical activity & Not meet WHO recommendation & 28 & 33.7 \\
& & Meet WHO recommendation & 55 & 66.3 \\
5 & BMI & Overweight \& obese & 52 & 62.7 \\
& & Normal & 30 & 36.1 \\
& & Underweight & 1 & 1.2 \\
6 & Blood pressure & Hypertension & 9 & 10.8 \\
& & Pre hypertension & 27 & 32.5 \\
\multirow{2}{*}{7} & Blood glucose & Normal & 47 & 56.6 \\
& & Diabetes & 3 & 3.6 \\
& & Pre diabetes & 6 & 7.2 \\
8 & Cholesterol & Normal & 74 & 89.2 \\
& & Hipercholesterolemia & 24 & 28.9 \\
& & Normal & 59 & 71.1 \\
\hline
\end{tabular}

The results of the univariate analysis of this study showed that majority respondents who met the inclusion and exclusion criterias are non academic staff, and many of them are janitors. Many academic staffs are reluctant to complete GPAQ questionnaire, due to their busy schedule during work hours when the health examination program was held.

Majority of respondents are in productive age (mean $=37,7$ years old). It means that UAD has a strong human resources who can work effective and efficiently if they are healthy. The distance from where the staff lives to UAD campus also become a concern. The distance from home to campus also determines whether they walk or use motorized vehicles. The farther the distance from home to campus, the less likely it is to walk to campus. Limited parking space can be an opportunity for leaders in UAD to support physical activity. Eventhough the majority of respondents met WHO recommendation for physical activity, the data from GPAQ questionnaires showed some overestimation of physical activity which is done by respondents. The respondents gave more value to household chores they had been done in the house even there were no increase in breathing and heart rate.

The overall health status data showed that many of the respondents are overweight and obese. Respondents in the age group in this study showed BMI problems. Research conducted by Parson \& Power showed that women who are physically active at the age of 16-42 will experience a slight change in BMI compared to women who are not physically active $(2.1 \mathrm{vs} 2.5 \mathrm{~kg} / \mathrm{m} 2 / 10$ years). Decreasing physical activity in men in adolescence to middle adulthood, and not being physically active in women in both stages of life can cause an increase in BMI [16].

The results of blood pressure measurements showed that $43.3 \%$ of respondents were hypertension and prehypertension. Those in the prehypertension category, in the future has a higher tendency to experience hypertension than those in the normotensive category. Uncontrolled hypertension for a long time (persistent) will damage to the kidneys (kidney failure), heart (coronary heart disease) and brain (causing strokes) [17], [18]. Meanwhile blood glucose and chlesterol measurement showed no significant problems.

\subsubsection{Bivariate analysis}

Chi square analysis between variables showed no relationship between physical activity and BMI, blood pressure, blood glucose, and cholesterol ( $p$ value $>0.05$ ). The overall results can be seen in Table 2 .

Table 2. P value beetween variables

\begin{tabular}{ll}
\hline Variable & Physical activity \\
\hline BMI & 0.826 \\
Blood pressure & 0.391 \\
Blood glucose & 0.439 \\
Cholesterol & 0.644 \\
\hline
\end{tabular}

Based on many studies, sedentary life style triggers many consequences. Physically inactive and uhealthy food increase prevalence of non-communicable diseases such as cardiovascular diseases, diabetes, cancer, and its risk factors such as high blood pressure, high blood glucose, and overweight [4]. In addition,

Health status and physical activity among academic and non academic staffs... (Nurul Qomariyah) 
physically inactive is the main contributor for 310,000 to 580,000 deaths that occur per year and produces disabilty due to diabetes, osteoporosis, obesity, and stroke [19].

People with disabilty which is produced by non communicable diseases will lose their productivity and increase the burden to the country. WHO meeting in Geneva in 2011 stated that health care cost for non communicable diseases absorbed more than one third of the country expenditure, and cardiovascular diseases is the one who spent the highest cost.

\subsection{Qualitative study}

The questions in the interview consisted of seven domains, namely: (1) current behavior and lifestyle, (2) geographical information, (3) awareness and knowledge, (4) values, beliefs and attitudes, (5) health, ability and the level of confidence, (6) cultural norms and social networks, (7) access and use of existing facilities.

Three respondents from active group and nine respondents from not phisically active group were interviewed. Individual and environment factors are identified as supporting and inhibiting factors for physically active. The resume of the factors can be seen in Table 3 .

Table 3. Supporting and inhibiting factors for physically active

\begin{tabular}{|c|c|}
\hline \multicolumn{2}{|r|}{ Supporting factors } \\
\hline \multirow{4}{*}{$\begin{array}{l}\text { Demands in the office and at home } \\
\text { Available time at home }\end{array}$} & $\begin{array}{l}\text { Non academic staff, male, } 52 \text { years old, healty: } \\
\text { "I go to my paddy field at } 5.30 \text { to } 6.30 \text { in the morning. Then I go to the } \\
\text { campus. And I go back to my paddy field at 3.30-5.30 in the } \\
\text { afternoon". }\end{array}$ \\
\hline & Non academic staff (janitor), male, 34 years old, healty: \\
\hline & "After work hours, I take a rest for a while at home. After Ashar time, I \\
\hline & $\begin{array}{l}\text { continue my work selling siomay with my motorcycle until } 9 \text { o'clock in } \\
\text { the evening" }\end{array}$ \\
\hline \multirow[b]{2}{*}{ High (self) motivation } & Non academic staff, female, 27 years old, healthy: \\
\hline & $\begin{array}{l}\text { "I like going up and down stairs in my house to hang the clothes" } \\
\text { "If I fell inconvinient with my clothes, it means that my body weight is } \\
\text { increasing, so I will do exercise" }\end{array}$ \\
\hline \multirow{2}{*}{$\begin{array}{c}\text { Supporting environment at home and at the } \\
\text { office }\end{array}$} & Non academic staff, female, 27 years old, healthy: \\
\hline & "My office is in the second floor, and I will go down to have my lunch" \\
\hline \multirow[t]{2}{*}{ Actively join sport organization } & Non academic staff (janitor), male, 34 years old, healty: \\
\hline & "I play bulutangkis at home with my friends" \\
\hline \multicolumn{2}{|r|}{ Inhibiting factors } \\
\hline \multirow{8}{*}{ Thight schedule in the office and at home } & Academic staff, female, 41 years old, overweight: \\
\hline & "I was tired when I was home" \\
\hline & Non academic staff, female 36 years old, overweight: \\
\hline & "I spent most of my time doing office work and housework" \\
\hline & Academic staff, male, 42 years old, healthy: \\
\hline & "I always have classes at seven in the morning until evening. Every day \\
\hline & I come home from work at eight o'clock in the evening" \\
\hline & $\begin{array}{l}\text { Academic staff, female, } 43 \text { years old, overweight, pre hypertension, } \\
\text { hyperuricemia: }\end{array}$ \\
\hline \multirow{2}{*}{$\begin{array}{l}\text { No support from husband/wife, friend, and } \\
\text { the authority }\end{array}$} & "My husband is not physically active" \\
\hline & $\begin{array}{l}\text { Non academic staff, male, } 38 \text { years, obese and hypertension: } \\
\text { "I like sports like outbound, together with friends and fun. But it can } \\
\text { not happen everyday" }\end{array}$ \\
\hline \multirow[t]{2}{*}{ Far distance from house to the campus } & Non academic staff, 36 years old, overweight: \\
\hline & $\begin{array}{l}\text { "I use motorcycle to go to the campus. But I use my bike to go } \\
\text { somewhere near" }\end{array}$ \\
\hline Low motivation & $\begin{array}{l}\text { Non academic staff, male, } 38 \text { years old, obese, hypertension: } \\
\text { "I am lazy when I am tired..." }\end{array}$ \\
\hline No network in sport organization & $\begin{array}{l}\text { Non academic staff, female, } 47 \text { years old, healthy: } \\
\text { "I don't join any sport organization, because it has the same time with } \\
\text { recitation (pengajian)" }\end{array}$ \\
\hline Lack of sport facilities & $\begin{array}{l}\text { Non academic staff, female, } 22 \text { years old, healthy: } \\
\text { "I only join aerobic every Saturday morning in the campus for } 60 \\
\text { minutes" }\end{array}$ \\
\hline No information about WHO & Non academic staff, female, 47 years old, healthy: \\
\hline recommendation & "I only join aerobic once a week for 60 minutes. Is it enough?" \\
\hline \multirow{4}{*}{$\begin{array}{l}\text { Injury history and other health related } \\
\text { problems }\end{array}$} & Academic staff, 28 years old, overweight: \\
\hline & $\begin{array}{l}\text { "I am still looking for sport which is convinient for my knee. I had } \\
\text { knee injury two years ago" }\end{array}$ \\
\hline & Non academic staff, female, 47 years old, healthy: \\
\hline & $\begin{array}{l}\text { "I can not do another jumping for sport since I was pregnant in the } \\
\text { age } 35 \text { years old" }\end{array}$ \\
\hline
\end{tabular}

Int. J. Eval. \& Res. Educ. Vol. 8, No. 1, March 2019: 97 - 102 
WHO has been published Global Recommendations on physical activity for health since 2010 . The recomendations aim to provide guidance on the dose-response relationship between physical activity and health benefits. Based on the results in this qualitative study, it was shown that most of the respondents do not know about this recommendation. They do not know the frequency, duration, intensity, type and total amount of physical activity needed for health enhancement and prevention of NCDs [4]. It is very important to socialize this recommendation especially among people who are working in higher education. Good understanding will help them to plan physical activities in their daily life.

Meanwhile, sedentary lifestyle and workload support them to be physyically inactive. Study findings highlight the difficulty in achieving sustained positive physical activity behaviour, particularly with sedentary participants [20]. Some of the respondents support physical activities program which are held in campus in working hour (ie, aerobic exercise). WHO recommendations stating that physical activity with moderate or high intensity must be carried out at least 10 minutes continuously, can be a guideline for leaders to keep parking space away from the campus. It will encourage staffs to do physical activity before and after participating in activities on campus.

A healthy, active campus recognizes the value of active living, physical activity and sport. It provides opportunities for physical activity and active living for all. Built and social environment are some important things that can be considered. Support from family and also leaders on campus are needed to encourage physical activities. The leaders must also provide opportunities for those with disabilities [5].

The location of UAD campus is in the city of Yogyakarta. It is a challenge for the leaders to support physical activities in limited land, time and opportunities to remain physically active. This is in line with the vision and mission of the Public Health faculty of UAD, namely superior in competition, has a global perspective, based on Islamic values and is oriented towards healthy city. The leader's commitment can be demonstrated by the existence of socialization, facilities and infrastructure that support physical activities.

Schools, from pre-school to university are important places to promote physically active lifestyles. Campus/university can educate and support all academic and non academic staff to start healthy and active lifestyle. Based on the results of qualitative research, it is showed that universities can create an environment that supports physical activity. Supports can be implemented in the form of providing facilities for physical activities such as a room with a treadmill, and other simple equipment to support aerobic physical activity and support all the staff to use stairs instead of elevators. The facilities for sports are expected to be accessible and low cost for the staff. This is important because staffs spend most of their time on campus. The socialization regarding recommendations for physical activity from WHO must also be carried out; accompanied by improving the skills to mange time and energy [21].

\section{CONCLUSION}

Being physically active plays an important role in ensuring health and well-being. Regular moderate intensity of physical activity will reduce the risk of non-communicable diseases. The majority of UAD staffs are physically active and overweight. No significant health problems are found. Individual, social and environmental factors are identified as factors that can support and inhibit physical activity. Policies at the faculty and university level are needed as well as cross-sectoral collaboration with related parties to support physical activities in UAD.

\section{REFERENCES}

[1] WHO, "Constitution of the World Health Organization: Principles," [Online] Available: http://www.who.int/about/mission/en/, 2017.

[2] Hancock, C., "Review the benefits of physical activity for health and well-being," C3 Collaborating for Health, 2011.

[3] WHO, "Physical Activity," [Online] Available: http://www.who.int/topics/physical_activity/en/, 2017.

[4] WHO, "Global recommendations on physical activity for health", 2010.

[5] Edwards, P. and Tsouros, A. D., "A Healthy City is an Active City: A Physical Activity Planning Guide", WHO, 2008.

[6] Indonesian Health Department, "Practical Guidelines for nutrition monitoring in adultsPedoman praktis memantau status gizi orang dewasa", 2011.

[7] Bhurosy, T. and Jeewon, R., "Overweight and Obesity Epidemic in Developing Countries: A Problem with Diet, Physical Activity, or Socioeconomic Status?," Scientific World Journal Volume, pp. 7, Retreived from http://dx.doi.org/10.1155/2014/964236, 2014.

[8] Heat, G. W., et al., "Evidence-based intervention in physical activity: lessons from around the world," The Lancet, vol. 380(9838), 2012.

[9] Marshall, A. L.,"Challenges and opportunities for promoting physical activity in the workplace," Journal of Science and Medicine in Sport, vol. 7(1), pp. 60-66, 2004.

Health status and physical activity among academic and non academic staffs... (Nurul Qomariyah) 
[10] Edmunds, S. Hurst, L. and Harvey, K., "Physical activity barriers in the workplace: An exploration of factors contributing to non-participation in a UK workplace physical activity intervention," International Journal of Workplace Health Management, 2013.

[11] Froiland, J. M., "Physical Education for Lifelong Fitness," EBSCO Research Starters: Salem Press Encyclopedia. Ipswich, MA. EBSCO, 2015.

[12] Muhammadiyah Council for Education, "Research, and Development in Higher Education (Majelis Diktilitbang Muhammadiyah)," Universitas Ahmad Dahlan Yogyakarta, 2018.

[13] Bull, F.C. Maslin, T.S. and Amstrong, T., "Global Physical Activity Questionnaire (GPAQ) Nine Country Reliability and Validity Study," Journal of Physical Activity and Health, vol. 6, pp. 790-804, 2009.

[14] Cleland, et al., "Validity of the Global Physical Activity Questionnaire (GPAQ) in assessing levels and change in moderate-vigorous physical activity and sedentary behaviour," BMC Public Health, vol. 14, pp. 1-11, 2014.

[15] Qomariyah, N. Astuti, F. D. Priambodho, A. A., "Physical activity among undergraduate students," Proceeding $4^{\text {th }}$ UPHEC, 2018.

[16] Parsons, T. J. Manor, O. Power, C., "Physical activity and change in body mass index from adolescence to midadulthood in the 1958 British cohort," International Journal of Epidemiology, vol. 35, pp. 197-204, 2006.

[17] Infodatin, "Hipertensi," Pusat Data dan Informasi Kementerian Kesehatan RI, 2014.

[18] US Department of Health and Human Services, "The Seven Report of the Joint National Committee on Prevention, Detection, Evaluation, and Treatment of High Blood Pressure, 2003.

[19] Macera, C. A., et al., "Promoting healthy eating and physical activity for a healthier nation," 2010.

[20] Scherrer, P. Henley, N. Sheridan, L. Sibson, R. and Ryan, M., "Maintaining momentum: the challenge of a workplace physical activity program to sustain motivation and activity." Journal for research and consumer, vol. 14, 2008.

[21] WHO, "Milestones in Health Promotion, Statements from Global Conferences," 2009.

Int. J. Eval. \& Res. Educ. Vol. 8, No. 1, March 2019: 97 - 102 